\title{
PENGARUH TAX AVOIDANCE RISK TERHADAP CASH HOLDING POLICY PERUSAHAAN DI INDONESIA
}

\author{
Yudi Tri Hardianto1), Nur Aisyah Kustiani2), Muhammad Rheza Ramadhan ${ }^{3)}$ \\ 1,3) Pegawai Kantor Pusat Direktorat Jenderal Pajak \\ 2) Dosen Jurusan Akuntansi Politeknik Keuangan Negara-STAN \\ E-mail: rhezakz@gmail.com
}

\begin{abstract}
Abstraksi
Penelitian ini bertujuan untuk mengetahui pengaruh Risiko Penghindaran Pajak terhadap Cash Holding Policy Perusahaan di Indonesia. Risiko Penghindaran Pajak diukur dengan proksi Cash Effective Tax Rate sedangkan Cash Holding Policy diukur dengan proxy Cash Ratio (cash and cash equivalent dibagi dengan total aset atau total penjualan). Berdasarkan hasil regresi dengan model random effect terhadap 74 sample, kami menemukan bahwa Tax Avoidance Risk tidak berpengaruh terhadap Cash Holding Policy setelah dikontrol dengan variabel market to book ratio, ukuran perusahaan, leverage, capital expenditure, volatility of cash flow, dividen, penelitian dan pengembangan, akuisisi, arus kas setelah pajak, dan sektor industri.
\end{abstract}

Kata Kunci: Penghindaran Pajak, Kebijakan Menahan Kas, Agresivitas Pajak, Cash ETR

\begin{abstract}
This study aims to determine the effect of Tax Avoidance Risk to Cash Holding Company Policy in Indonesia. Tax Avoidance Risk is measured by Cash Effective Tax Rate proxy and Cash Holding Policy is measured by Cash Ratio proxy (cash and cash equivalent divided by total asset or total sales). Based on regression with random effect model on 74 samples, we found that Tax Avoidance Risk has no effect on Cash Holding Policy after controlled by market to book ratio variable, firm size, leverage, capital expenditure, volatility of cash flow, dividend, research and development, Acquisitions, cash flow after tax, and industrial sector.
\end{abstract}

Keywords : Tax Avoidance, Cash Holding Policy, Tax Aggressiveness, Cash ETR

\section{PENDAHULUAN}

\section{Latar Belakang}

Bagaimana jika suatu laporan keuangan tidak menampilkan keadaan sebenarnya dari perusahaan? Bagaimana jika keuntungan suatu perusahaan lebih kecil dari yang seharusnya terjadi? Jika hal tersebut terjadi maka tujuan dari laporan keuangan untuk memberikan informasi kondisi perusahaan tidak sampai kepada pengguna (Bragg, 2012). Pengguna laporan keuangan seharusnya mendapatkan informasi mengenai keadaan perusahaan sesuai dengan yang tercermin dalam laporan keuangan. Laporan keuangan seringkali dianggap sebagai potret kondisi laporan keuangan pada suatu waktu tertentu (Schmidt, 2016). Potret ini harusnya bisa dijadikan sebagai tolak ukur keadaan suatu perusahaan.

Laporan keuangan perusahaan selain digunakan oleh investor juga digunakan oleh pemerintah (Hanlon, Hoopes, \& Shroff, 2014). Ketika investor berfikir tentang adanya keuntungan investasi, maka dari sisi pemerintah adalah pajak yang seharusnya dibayar oleh perusahaan. Dalam hal ini perusahaan tentunya berbeda kubu dengan pemerintah (Hanlon, 
Hoopes, \& Shroff, 2014). Perusahaan yang selalu mencari keuntungan yang sebesar-besarnya tetapi berharap tidak membayar pajak. Menurut mantan Menteri Keuangan, Bambang Brodjonegoro, sebanyak 2000 perusahaan asing di Indonesia tidak membayar pajak selama 10 tahun terakhir, laporan keuangan yang ditampilkan oleh perusahaan tersebut mengakui rugi, padahal menurut penelitian Ditjen Pajak harusnya membayar rata-rata Rp25 Milyar setahun (Detik.com, 2016). Perusahaan menaikkan laba ketika pelaporan dalam pasar modal dan sebaliknya akan melaporkan laba yang lebih sedikit ketika melaporkannya kepada otoritas perpajakan (Desai, 2005).

Perusahaan yang melakukan tindakan penghindaran pajak menggunakan berbagai cara untuk menggelapkan pajaknya (Sikka \& Hampton, 2005). Skema yang dilakukan oleh perusahaan antara lain dengan cara memanipulasi pajak penghasilan badan, pajak atas penjualan, dan dengan memanipulasi pajak atas gaji. Selain itu perusahaan juga menggunakan skema kebijakan menahan kas untuk penghindaran pajak (Hanlon \& Maydew, 2013).

Perusahaan menggunakan manajemen kas dalam memanipulasi laporan keuangan untuk beberapa alasan (Dhaliwal, et al, 2011). Alasan yang pertama berkaitan dengan motif transaksi dan alasan yang kedua berkaitan dengan motif berjaga-jaga berkaitan penggunaan dan kepemilikan kas di masa datang. Perusahaan juga melakukan kebijakan menahan kas dengan alasan skala keekonomisan dari suatu perusahaan (Mulligan, 1997). Perusahaan pun beralasan menahan kas untuk mengantisipasi akan mahalnya biaya konversi non-kas aset menjadi kas (Miller \& Orr, 1966). Perusahaan akan menahan kas lebih besar jika menghadapi masalah keagenan (agency problem) yang berisiko tinggi (Dittmar, Mahrt-Smith, \& Servaes, 2003). Perusahaan akan menahan kas ketika masalah keagenan semakin parah, uang menjadi semakin tidak bernilai (Dittmar, 2005). Selain itu perusahaan menahan kas dikarenakan risiko pajak yang akan timbul di masa datang (Foley, et al, 2007).

Perusahaan-perusahaan yang ada di Indonesia juga melakukan manajemen kas. Beberapa diantaranya adalah PT Adaro Energy Tbk, Indo Tambangraya Megah Tbk, serta Tambang Batubara Bukit Asam Tbk memiliki presentase kenaikan kas setiap tahunnya. Bukit asam, pada tahun 2004 hanya memegang kas sejumlah Rp993.730 juta menjadi Rp5.054.075 juta pada tahun 2010 atau naik sebesar 409\% dari tahun 2006. Indo Tambangraya Megah menahan kas pada tahun 2005 hanya Rp154.488 juta dan naik menjadi Rp2.648.469 juta pada tahun 2010 atau naik sebesar 1614\% dari tahun 2005. Kenaikan kas juga terjadi pada Adaro. Adaro tahun 2007 memegang kas dalam jumlah Rp831.840 juta dan naik menjadi Rp5.459.971 juta atau naik sebesar 556\% dari tahun 2007 (data diolah dari IDX). Dalam rentang tahun-tahun tersebut perusahaan-perusahaan terlilit beberapa kasus pajak. Seperti yang dijelaskan oleh koordinator pusat data dan analisis ICW, Firdaus Ilyas, perusahaan tambang seperti Adaro, Indo 
Tambangraya Megah, Bumi Resources, Bukit Asam, dan Medco banyak menghadapi masalah perpajakan (Hukumonline.com, 2009).

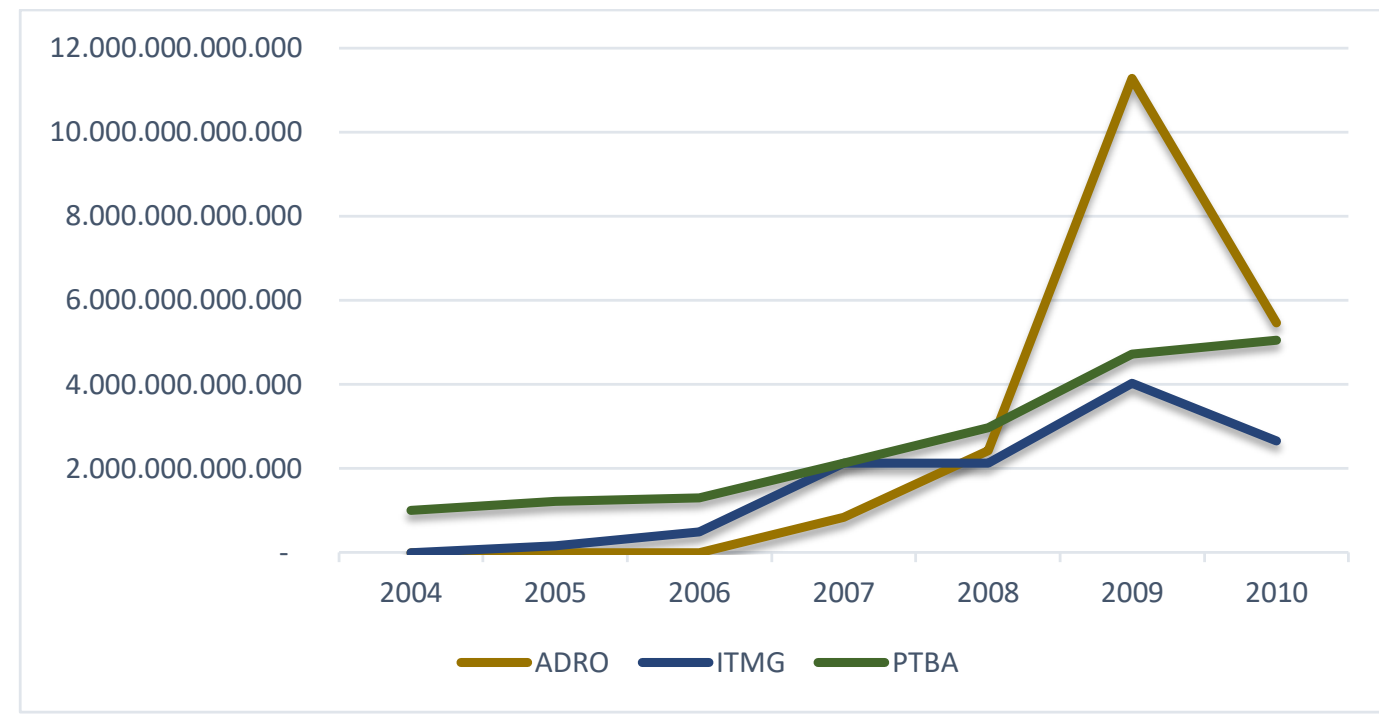

Gambar 1 Perubahan Kas Perusahaan

Sumber: diolah penulis dari data BEI tahun 2004-2010

Dengan melihat kondisi bahwa banyak perusahaan yang menahan kas dalam jumlah besar seperti yang dilakukan oleh perusahan seperti Adaro, Indo Tambangraya Megah, serta Bukit Asam, serta resiko penghindaran pajak yang dilakukan oleh perusahaan tersebut, maka penulis menguji pengaruh antara risiko penghindaran pajak dengan kas yang ditahan oleh perusahaan. Melihat kondisi diatas maka penulis mengangkat pertanyaan penelitian yaitu "adakah pengaruh risiko penghindaran pajak terhadap kebijakan penahanan kas (cash holding) perusahaan?"

\section{Perumusan Masalah}

Berdasarkan latar belakang penelitian yang telah dipaparkan sebelumnya, perumusan masalah dalam penelitian ini adalah "Apakah risiko penghindaran pajak berpengaruh terhadap kebijakan penahanan kas (cash holding) perusahaan?"

\section{Tujuan Penelitian}

Berdasarkan masalah penelitian yang telah dijelaskan di atas, tujuan penelitian ini adalah untuk mengetahui adakah pengaruh risiko penghindaran pajak terhadap kebijakan menahan kas (cash holding) suatu perusahaan yang terdaftar di BEI.

\section{Kegunaan Penelitian}


Penelitian ini diharapkan dapat berkontribusi positif dalam sisi pengetahuan, penelitian, dan otoritas perpajakan sebagai pembuat kebijakan. Beberapa manfaat yang diharapkan dari penelitian ini diharapkan dapat menjelaskan pengaruh risiko penghindaran pajak terhadap kebijakan menahan kas (cash holding) suatu perusahaan yang terdaftar di BEI, dapat menjadi bahan referensi bagi DJP untuk melakukan analisis lanjutan serta memperbaiki anti-avoidance rules yang terdapat di ketentuan peraturan perpajakan di Indonesia, dan dapat memberikan wawasan dan pengetahuan kepada masyarakat mengenai akuntansi serta perpajakan, khususnya mengenai praktik kebijakan perusahaan yang bisa menimbulkan suatu risiko penghindaran pajak perusahaan yang ada di Indonesia

\section{TINJAUAN PUSTAKA DAN PERUMUSAN HIPOTESIS}

\section{Tinjauan Literatur}

\section{Teori Keagenan (Agency Theory)}

Hubungan keagenan menurut Jensen \& Meckling (1976) adalah suatu hubungan yang terjadi karena adanya kontrak antara pemilik perusahaan (principal) dengan seseorang/manajer (agent) untuk menjalankan beberapa pekerjaan sesuai dengan keinginan pemilik perusahaan. Pemilik dalam hal ini merujuk kepada pemegang saham, sedangkan yang dimaksud dengan agen ini adalah manajer. Pekerjaan yang dilakukan agen merupakan pendelegasian wewenang hasil dari hubungan antara pemilik dan manajer untuk mengambil keputusan.

Manajer selaku agen dari pemilik perusahaan, terkadang membuat keputusan yang tidak optimal dan bertentangan dengan kepentingan pemilik (Jensen \& Meckling, 1976). Manajer diharapkan oleh pemilik untuk memaksimalkan kesejahteraan pemilik, namun di sisi lain manajer juga berkepentingan dengan memaksimalkan kesejahteraan dirinya sendiri. Perbedaan kepentingan ini yang akhirnya membuat konflik kepentingan yang disebut dengan masalah keagenan (agency problem). Chege (2014) membagi masalah keagenan ini menjadi tiga bagian. Masalah-masalah yang terjadi adalah masalah antara: (1) pemilik (principal) dan manajer (agent); (2) pemegang saham mayoritas (agent) dengan pemegang saham minoritas (principal) dari perusahaan; (3) perusahaan yang diwakili oleh manajer dengan pihak luar yang berhubungan perusahaan, seperti kreditor, pegawai, pemerintah dan pelanggan.

Masalah keagenan ini memunculkan biaya yang dinamakan agency cost. Jensen \& Meckling (1976) menguraikan bahwa agency cost merupakan jumlah dari (1) biaya yang dikeluarkan pemilik untuk mengawasi dan mengendalikan perilaku manajer, (2) biaya untuk mengikat pengeluaran manajer untuk menjamin bahwa manajer tidak bertindak merugikan pemilik, dan (3) residual loss, merupakan pengurangan kekayaan pemilik akibat adanya 
Pengaruh Tax Avoidance Risk Terhadap Cash Holding ...

perbedaan antara keputusan manajer dan keputusan yang seharusnya untuk memaksimalkan kekayaan pemilik.

\section{Kas yang Ditahan (Cash Holding)}

Ada empat teori tentang kebijakan menahan kas (cash holding) menurut Hanlon \& Maydew (2013):

\section{Motif Biaya Transaksi}

Perusahaan akan menahan kas untuk menghindari biaya yang timbul jika perusahaan tersebut ingin mengkonversi aset non-kas menjadi kas (Baumol, 1952; Miller \& Orr, 1966). Perusahan yang memiliki skala ekonomis yang besar akan menahan uang dalam jumlah yang lebih sedikit (Mulligan, 1997).

\section{Motif Pencegahan}

Perusahaan menggunakan motif pecegahan atau melakukan tindakan hati-hati untuk menghadapi situasi pasar yang tidak kondusif. Motif pencegahan juga dilakukan oleh perusahan ketika akses ke pasar modal menjadi lebih mahal. Perusahaan yang mempunyai arus kas yang terlalu berisiko atau kurang stabil akan lebih mengupayakan untuk menahan kas (Opler, et al, 1999).

\section{Motif Keagenan}

Manajer perusahaan akan menahan kas untuk tujuan mereka sendiri (Jensen \& Jensen, 1986) daripada untuk membaginya dalam bentuk dividen. Perusahaan juga akan menahan banyak uang kas jika pada negara tersebut ditemui banyak masalah keagenan (Dittmar, MahrtSmith, \& Servaes, 2003). Bahkan jika masalah keagenan ini semakin parah maka perusahaan akan lebih banyak menahan kas, karena kas ini lebih tidak bernilai (Faulkender \& Wang, 2006).

\section{Motif Penghindaran Pajak}

Pajak menjadi salah satu tujuan dari kebijakan menahan kas. Perusahaan sebisa mungkin menahan transaksi jika transaksi tersebut berkaitan dengan pajak, sehingga kas yang dimiliki perusahaan akan menumpuk (Foley, et al, 2007). Begitu juga dengan perusahaan yang dikenai pajak diluar negeri oleh otoritas pajak di negara tersebut (Pfanner, 2012).

\section{Penghindaran Pajak (Tax Avoidance)}

Teori tentang penghindaran pajak diteliti mulai dari penentu penghindaran pajak maupun akibat yang ditimbulkan oleh penghindaran pajak. Penentu atau penyebab dari penghindaran pajak ini bisa diakibatkan oleh kepemilikan (Chen, et al, 2010), pengaruh dari manajer (Dyreng, Hanlon, \& Maydew, 2010), skala ekonomi perusahan dan akibat dari kompensasi atas performa perusahaan. Penghindaran pajak juga menimbulkan efek terhadap reputasi perusahaan (Hanlon \& Slemrod, 2009) dan memberikan hipotesis serta menemukan 
fakta bahwa penghindaran pajak berpengaruh positif dengan risiko jatuhnya harga saham (Kim, Li, \& Zhang, 2011).

\section{Hasil Penelitian Sebelumnya}

Penelitian mengenai pengaruh antara risiko penghindaran pajak terhadap kebijakan perusahaan dalam menahan kas belum mendapatkan perhatian di kalangan peneliti pajak di bidang akuntansi (Hanlon \& Maydew, 2013). Penulis menggunakan penelitian dari Hanlon, Maydew, dan Saavedra (2014) sebagai rujukan. Hanlon \& Maydew (2013) melakukan penelitian tentang pengaruh risiko penghindaran pajak dan kebijakan perusahaan menahan kas (cash holding). Dalam penelitiannya, Hanlon \& Maydew (2013) mengambil sampel perusahaan di Amerika Serikat. Penelitian tersebut menggunakan Cash Effective Tax Rate (Cash ETR) dalam menentukan risiko penghindaran pajak sebagai variabel bebas. Cash ETR yang dipakai adalah model yang dipakai oleh Dyreng, Hanlon, \& Maydew (2008) didefinisikan sebagai jumlah pajak yang dibayar dibagi dengan dengan jumlah penghasilan sebelum pajak. Penelitian tersebut menunjukkan bahwa ada pengaruh yang positif antara risiko penghindaran pajak dengan cash holding. Ketika suatu perusahaan terindikasi melakukan suatu risiko penghindaran pajak maka perusahaan akan melakukan kebijakan cash holding. Hanlon, Maydew, \& Saavedra, (2014) melakukan penelitian tentang pengaruh antara uncertainty tax benefit dan pengaruhnya terhadap cash holding. Penelitian ini merupakan penelitian lanjutan dari Hanlon, M \& Maydew (2013). Dalam penelitian ini mengubah model regresi yang dibuat sebelumnya dengan mengganti variabel bebas dengan uncertainty tax benefit yang berlaku di Amerika Serikat. Tax Risk yang sebelumnya dijadikan sebagai variabel bebas diganti menjadi variabel kontrol. Dalam penelitian ini Hanlon, Maydew, \& Saavedra (2014) menemukan pengaruh yang positif antara ketidakpastian pajak yang dialami oleh perusahaan dengan kebijakan cash holding yang dilakukan oleh perusahaan.

\section{Hipotesis Penelitian}

Perumusan hipotesis dalam penelitian ini berangkat dari hasil penelitian Hanlon \& Maydew (2013) mengenai pengaruh antara risiko penghindaran pajak terhadap kebijakan perusahaan untuk menahan kas. Hasil penelitiannya mengindikasikan terjadinya pengaruh yang positif antara risiko penghindaran pajak terhadap kebijakan perusahaan untuk menahan kas. Berdasarkan landasan teori dan pembuktian pada penelitian-penelitian terdahulu dapat dirumuskan hipotesis yaitu: risiko penghindaran pajak berpengaruh positif terhadap kebijakan perusahaan menahan kas, cateris paribus.

\section{METODE PENELITIAN}

\section{Pengambilan Sampel}

Tujuan dari penelitian ini adalah untuk mengetahui pengaruh risiko penghindaran pajak 
Pengaruh Tax Avoidance Risk Terhadap Cash Holding ...

terhadap kebijakan perusahan menahan kas (cash holding). Subjek penelitian ini adalah perusahaan sektor non-keuangan yang terdaftar di Bursa Efek Indonesia. Objek penelitian yang akan diambil dalam penelitian ini berupa data sekunder yang diperolah dari perusahaan yang terdaftar di BEI dalam kurun waktu 2009 s.d. 2015. Pemilihan multi tahun (data panel) untuk memberikan gambaran dari pengaruh penghindaran pajak terhadap kebijakan cash holding yang dilakukan oleh beberapa perusahaan dalam kurun waktu tertentu. Menurut Sugiyono (2010), populasi adalah wilayah generalisasi yang terdiri atas obyek atau subyek yang mempunyai kualitas dan karakteristik tertentu yang ditetapkan oleh peneliti untuk dipelajari dan kemudian ditarik kesimpulannya. Sesuai dengan pengertian diatas, populasi pada penelitian ini populasinya adalah perusahaan yang terdaftar di BEI.

Pengambilan data laporan keuangan perusahaan ini terdiri dari dua bagian. Bagian pertama adalah pra observasi yang berlangsung selama lima tahun (2009-2013). Pada bagian ini digunakan untuk memperhitungkan long run Cash ETR dari perusahaan yang diobservasi. Bagian kedua merupakan data tahun 2014 dan 2015 yang digunakan untuk menghitung variabel-variabel lain yang mendukung penelitian ini.

Beberapa sampel yang representatif akan diambil untuk selanjutnya diolah dan dilakukan analisis sesuai dengan metode yang telah dipilih. Sampel ini merupakan bagian dari jumlah dan karakteristik yang dimiliki oleh populasi (Sugiyono, 2010). Pemilihan sampel ini dilakukan dengan cara purposive sampling (judgement sampling) yang merupakan bagian dari metode non-probability sampling, yaitu pemilihan sampel secara tidak acak dengan kriteriakriteria tertentu. Terkait hal ini, anggota populasi yang tidak memenuhi syarat, tidak dipilih sebagai sampel penelitian.

Pemilihan sampel dilakukan berdasarkan kriteria-kriteria yang telah ditentukan yaitu: (1) Perusahaan yang telah terdaftar di BEI dan menerbitkan laporan keuangan secara konsisten tahun 2009 sampai dengan 2015; (2) Perusahaan yang tidak masuk dalam kelompok perusahaan keuangan; (3) Perusahaan yang penghasilannya tidak dikenakan Pajak Penghasilan ( $\mathrm{PPh}$ ) final; (4) Perusahaan dengan nilai pembayaran pajak tidak minus dan, atau memiliki penghasilan sebelum pajak bernilai positif selama tahun 2009-2013.

\section{Jenis Data dan Cara Memperoleh Data}

Jenis data yang digunakan dalam penelitian ini merupakan data sekunder. Data ini berupa kumpulan data yang secara tidak langsung bersumber dari pihak lain dimana pihak tersebut secara tidak langsung memberikan data yang telah diolah lebih lanjut untuk kemudian data tersebut disajikan kepada pihak lain (Sugiyono, 2010). Menurut Soewadji (2012) data sekunder merupakan data yang diperoleh melalui bahan kepustakaan, bisa berupa dokumen, atau dalam bentuk publikasi yang sudah dalam bentuk jadi. 
Sumber sekunder dalam penelitian ini berupa laporan tahunan atau laporan keuangan perusahaan-perusahaan yang telah terdaftar pada Bursa Efek Indonesia (BEI) dalam kurun waktu tahun 2009 sampai dengan tahun 2015. Data sekunder ini dapat diperoleh baik dari www.idx.co.id, Indonesian Capital Market Directory (ICMD), maupun dari sumber-sumber lainnya yang dianggap sesuai dengan penelitian yang dilakukan.

\section{Variabel dan Definisi Operasional Variabel}

\section{Variabel Bebas}

Sugiyono (2010) menjelaskan bahwa variabel bebas adalah variabel yang mempengaruhi atau yang menjadi sebab perubahannya atau timbulnya variabel terikat. Dalam penelitian ini terdapat variabel bebas yaitu Tax Risk (Risiko Penghindaran Pajak).

Risiko Penghindaran Pajak. Pengukuran risiko penghindaran pajak ini menggunakan model dari Dyreng, Hanlon, \& Maydew (2008) yaitu the firm's cash effective tax rate. Cash ETR diukur dari jumlah pembayaran pajak secara tunai dibagi dengan penghasilan sebelum pajak. Cash ETR yang semakin tinggi berimplikasi kepada tingkat penghindaran pajak yang lebih rendah dari perusahaan dan sebaliknya (Dyreng, Hanlon, \& Maydew, 2008). Model ini dinyatakan sebagai berikut:

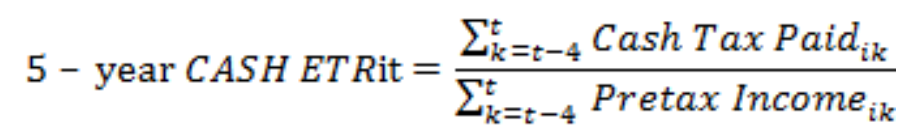

Keterangan:

5-year Cash ETR it $\quad=$ Long run effective tax rate (Dihitung dari jumlah pembayaran pajak secara tunai selama lima tahun sebelum tahun observasi dibagi dengan jumlah penghasilan sebelum pajak selama lima tahun sebelum observasi)

\section{Variabel Terikat}

Variabel terikat dijelaskan sebagai variabel output (Sugiyono, 2010). Lebih jauh lagi Sugiyono (2010) menjelaskan bahwa variabel terikat merupakan variabel yang dipengaruhi atau variabel yang menjadi akibat, karena adanya variabel bebas. Dalam buku lain, Sekaran (2006) menjelaskan bahwa variabel terikat adalah variabel yang menjadi tujuan utama dari suatu penelitian.

Variabel terikat yang penulis pilih dalam penelitian ini adalah cash ratio. Cash Ratio ini dihitung dengan membagi kas dengan total aset dari perusahaan sebagaimana telah dilakukan oleh Bates, Kahle, dan Stulz (2009).

\section{Variabel Kontrol}

Penelitian ini menggunakan banyak variabel kontrol atau pengendali. Variabel 
pengendali ini adalah variabel yang dikendalikan atau dibuat konstan sehingga pengaruh variabel bebas terhadap terikat tidak dipengaruhi oleh faktor lain yang tidak diteliti (Sugiyono, 2010). Definisi operasional dan perhitungannya akan dijelaskan sebagai berikut.

Market to Book Ratio adalah variabel kontrol untuk melihat kesempatan pertumbuhan suatu perusahaan i pada tahun t. Perusahaan dengan kesempatan untuk tumbuh dengan cepat akan menahan kas untuk membiayai kebutuhan dari perusahaan tersebut. Variabel ini dihitung dengan membagi nilai buku aset dikurangi nilai buku ekuitas ditambah nilai pasar ekuitas dengan nilai buku aset.

Firm Size adalah variabel kontrol melihat ukuran suatu perusahaan i pada tahun $t$. Perusahaan besar biasanya akan memegang sedikit kas, hal ini disebabkan oleh kemudahan dalam masuk dalam pasar modal sehingga mudah untuk memperoleh kas dari penjualan instrumen ekuitasnya. Variabel ini dihitung dengan log dari total aset.

Leverage adalah variabel kontrol melihat perusahaan i pada tahun $t$ dengan leverage yang tinggi dapat menggunakan kas untuk membayar hutang dan potensi biaya yang timbul untuk suatu keadaan yang mendesak. Variabel ini dihitung dari hutang jangka panjang ditambah dengan hutang jangka pendek dibagi dengan nilai buku aset.

Capex adalah variabel kontrol untuk melihat investasi perusahaan i pada tahun $\mathrm{t}$ akan berbanding terbalik dengan kebijakan menahan kas suatu perusahaan. Variabel ini dihitung dari rasio antara investasi perusahaan dibagi dengan nilai buku aset.

Volatility of Cash Flow adalah variabel kontrol untuk melihat perusahaan i pada tahun $\mathrm{t}$ akan menahan uang kas lebih besar jika arus kas perusahaan pada kondisi yang berbahaya. Variabel ini dihitung dari standar deviasi perubahan tahunan EBITDA empat tahun terakhir dibagi dengan rata-rata aset non kas di periode yang sama.

Dividend adalah variabel kontrol untuk melihat perusahaan i pada tahun $\mathrm{t}$ akan menahan lebih sedikit kas pada saat membagikan dividen pada tahun i. Variabel dummy dimana jika ada dividen nilainya 1 jika tidak ada maka nilainya 0 .

Research n Development adalah variabel kontrol untuk melihat perusahaan i pada tahun $\mathrm{t}$ jika melakukan investasi di bidang penelitian dan pengembangan akan menahan kas lebih besar. Variabel ini dihitung dari biaya penelitian dan pengembangan dibagi dengan total aset, jika tidak ada biaya penelitian dan pengembangan maka nilainya 0 .

Acquisition adalah variabel kontrol untuk melihat perusahaan yang melakukan akuisisi akan memiliki jumlah kas yang lebih sedikit di akhir tahun. Variabel ini dihitung dari biaya akuisisi dibagi dengan nilai buku aset yang terdapat di laporan keuangan perusahaan.

After Tax Cash Flow adalah variabel kontrol untuk melihat nilai dari arus kas setelah pajak dari perusahaan i pada tahun t. Variabel ini dihitung dari arus kas sebelum depresiasi dibagi dengan nilai buku aset. 
IND adalah dummy variable untuk mengetahui klasifikasi perusahaan sesuai pengelompokan yang digunakan oleh BEI selaku otoritas perdagangan saham emiten di Indonesia. Klasifikasi industri yang digunakan dalam penelitian ini adalah Jakarta Stock Exchange Industrial Classification (JASICA). Sektor keuangan serta sektor properti dan real estate lembaga dikeluarkan dalam penelitian ini. Kode 1 pada variabel pengendali IND diberikan apabila perusahaan termasuk dalam salah satu klasifikasi industri JASICA, selain itu 0.

Tahun adalah variabel pengendali untuk mengendalikan perbedaan kejadian mengenai agresivitas pajak yang terjadi selama tahun penelitian, 2013-2015. YR adalah dummy variable, diberikan kode 1 untuk membedakan agresivitas pajak yang terjadi pada masa penelitian tertentu, antara 2013, 2014, atau 2015, selain itu 0.

\section{Model Penelitian}

Model penelitian utama ini menggunakan regresi yang berasal dari penelitian yang dilakukan oleh Hanlon, M \& Maydew (2013). Model yang digunakan adalah memakai cash ratio yang didefinisikan sebagai cash to assets ratio diambil dari penelitian Bates, Kahle, dan Stulz (2009) yang dipakai dalam menentukan cash holding perusahaan. Tax Risk menggunakan model yang dijelaskan sebelumnya untuk menentukan risiko peghindaran pajak. Model penelitian ini menggunakan beberapa variabel kontrol. Model penelitian utama dari penelitian ini adalah sebagai berikut:

$$
\text { Cash Ratio }_{i t}=\alpha_{o}+\beta_{1} \text { Tax Risk }_{i t}+\sum \beta_{c} \text { Control }_{\text {cit }}+\varepsilon_{i t}
$$

Atau lebih lengkapnya adalah

$$
\begin{aligned}
\text { Cash Ratio }_{i t} & =\alpha_{o}+\beta_{1} \text { Tax Risk }_{i t}+\beta_{2} \text { MarkettoBookRatio }_{i t}+\beta_{3} \text { FirmSize }_{i t} \\
& +\beta_{4} \text { Laverage }_{i t}+\beta_{5} \text { Capex }_{i t}+\beta_{6} \text { VolatilityofCashFlow }_{i t} \\
& +\beta_{7} \text { Dividend }_{i t}+\beta_{8} \text { RnD }_{i t}+\beta_{9} \text { Aquisition }_{i t}+\beta_{10} \text { AfterTaxCashFlow }_{i t} \\
& +\beta_{11-15} \text { IND }_{i t}+\beta_{16} \text { Tahun }_{i t}+\varepsilon_{i t}
\end{aligned}
$$

Keterangan:

i

$\mathrm{t}$

$=$ Perusahaan sampel

$=$ Tahun 2014-2015

Cash Ratio $_{i t} \quad=$ Rasio kas perusahaan i pada tahun t. Dihitung dengan cara (1) kas dan setara kas dibagi dengan aset (2) kas dan setara kas dibagi dengan penjualan

Tax Risk $_{i t} \quad$ = Risiko Penghindaran Pajak perusahaan i pada tahun t. Dihitung dengan menggunakan 5-year Cash ETR

Control $_{\text {cit }} \quad=$ Variabel kontrol perusahaan i pada tahun $\mathrm{t}$

Jenis-Jenis Variabel Kontrol

Market-to-book = Variabel kontrol untuk melihat kesempatan pertumbuhan suatu ratio $_{\text {it }}$ perusahaan i pada tahun t. Perusahaan dengan kesempatan untuk tumbuh dengan cepat akan menahan kas untuk membiayai kebutuhan dari perusahaan tersebut. 
Dihitung dengan membagi nilai buku aset dikurangi nilai buku ekuitas ditambah nilai pasar ekuitas dengan nilai buku aset.

Firm Size Fit $_{2} \quad$ Variabel kontrol untuk melihat ukuran suatu perusahaan i pada tahun t. Perusahaan besar biasanya akan memegang sedikit kas, hal ini disebabkan oleh kemudahan dalam masuk dalam pasar modal.

Dihitung dengan log dari total aset.

Leverage $_{i t} \quad=\quad$ Variabel kontrol untuk melihat perusahaan i pada tahun $\mathrm{t}$ dengan Leverage yang tinggi dapat menggunakan kas untuk membayar hutang dan potensi biaya yang timbul untuk suatu keadaan yang mendesak.

Dihitung dari hutang jangka panjang ditambah dengan hutang jangka pendek dibagi dengan nilai buku aset.

Capital $=$ Variabel kontrol untuk melihat Investasi perusahaan $\mathrm{i}$ pada tahun $\mathrm{t}$ Expenditure $_{i t} \quad$ akan berbanding terbalik dengan kebijakan menahan kas suatu perusahaan.

Dihitung dari rasio antara invetasi perusahaan dibagi dengan nilai buku aset.

Volatility of cash $=$ Variabel Kontrol untuk melihat perusahaan $\mathrm{i}$ pada tahun $\mathrm{t}$ akan flow $_{\text {it }}$ menahan uang kas lebih besar jika arus kas perusahaan pada kondisi yang berbahaya.

Dihitung dari standar deviasi perubahan tahunan EBITDA empat tahun terakhir dibagi dengan rata-rata aset non kas di periode yang sama.

Dividend Payout $=$ Variabel Kontrol untuk melihat perusahaan $\mathrm{i}$ pada tahun $\mathrm{t}$ akan dummyit menahan lebih sedikit kas pada saat membagikan dividen pada tahun i. Variabel dummy dimana jika ada dividen nilainya 1 jika tidak ada maka nilainya 0.

Research and $=$ Variabel kontrol untuk melihat perusahaan $\mathrm{i}$ pada tahun $\mathrm{t}$ jika Development $_{\text {it }} \quad$ melakukan investasi di bidang penelitian dan pengembangan akan menahan kas lebih besar.

Dihitung dari biaya penelitian dan pengembangan dibagi dengan total aset, jika tidak ada biaya penelitian dan pengembangan maka nilainya 0 .

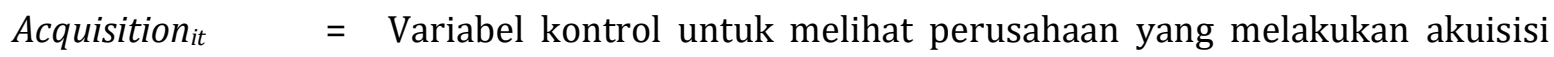
akan memiliki jumlah kas yang lebih sedikit di akhir tahun.

Dihitung dari biaya akuisisi dibagi dengan nilai buku aset.

After-tax cash = Variabel kontrol untuk melihat nilai dari arus kas setelah pajak dari flow $_{\text {it }} \quad$ perusahaan i pada tahun $\mathrm{t}$.

Dihitung dari arus kas sebelum depresiasi dibagi dengan nilai buku aset.

$I N D_{i t} \quad=$ dummy variable, diberikan kode 1 bila perusahaan termasuk dalam salah satu kategori sektor industri Jakarta Stock Exchange Industrial Clasiffication (JASICA), selain itu 0

Tahun $_{i t}=$ dummy variable, diberikan kode 1 bila tahun tersebut memenuhi kriteria spesifik, selain itu 0

E

$=$ Error

Model penelitian utama di atas merupakan adaptasi dari model penelitian Hanlon \& Maydew (2013) yang berjudul "Understanding Why Firms Hold so Much Cash: a Tax Risk Explanation" dengan penyesuaian pada variabel kontrol yaitu biaya pajak repatriasi (tax repatriation cost) yang tidak ada di Indonesia. Tax Repatriation Cost ini baru terjadi pada masa program Pengampunan Pajak (Tax Amnesty), namun dalam masa penelitian hal ini belum terjadi di Indonesia. 
Untuk memudahkan penggambaran hubungan antara variabel bebas dan variabel kontrol terhadap variabel terikat, maka model penelitian tersebut dapat dilihat dalam Gambar 2. Model Penelitian.

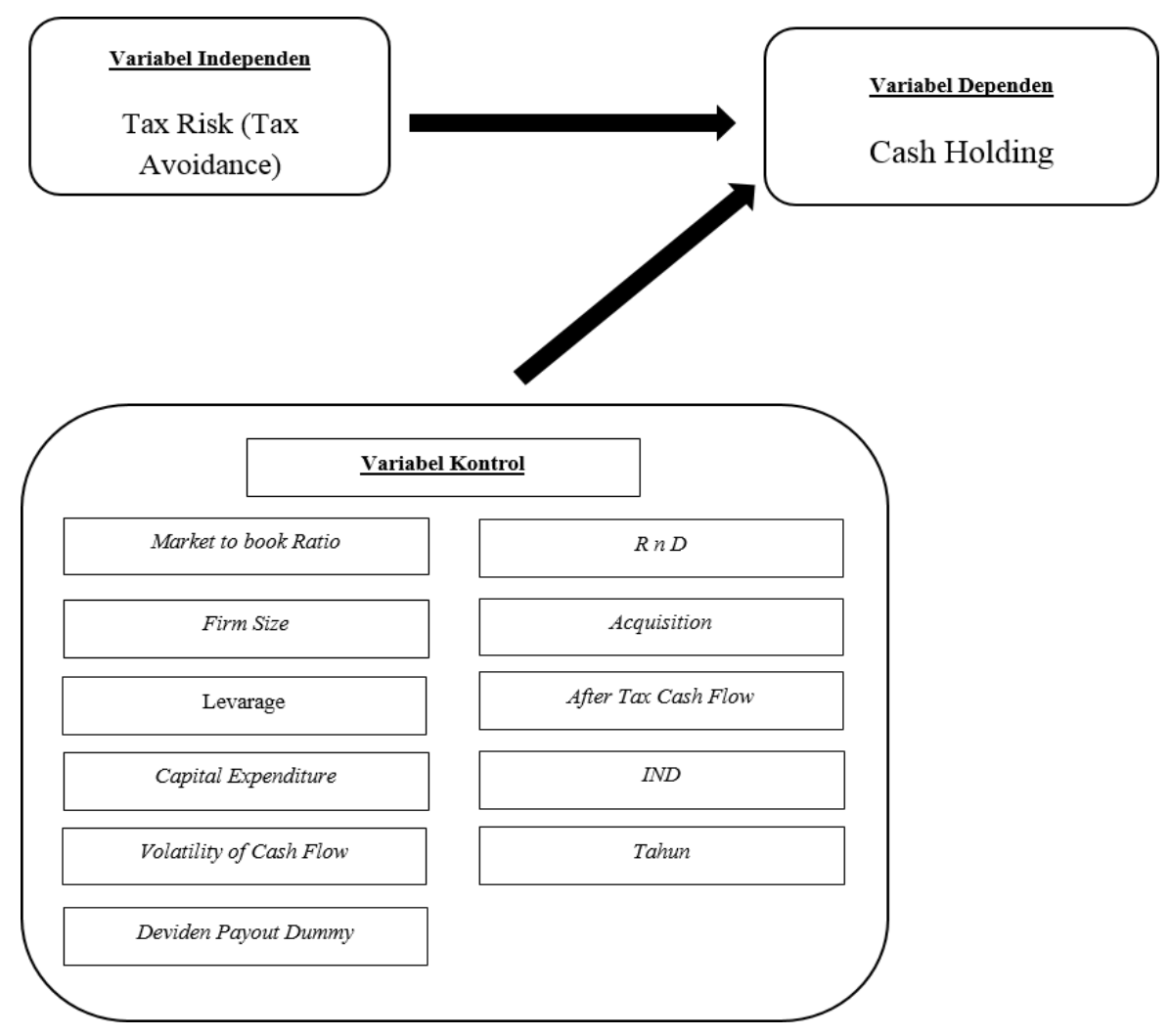

Gambar 2 Model Penelitian

Sumber: Diolah penulis dari model penelitian

\section{Cara Pengujian Hipotesis (Pengolahan Data)}

Peneliti menggunakan statistik deskriptif sebagai langkah awal dalam menginterpretasi data. Menurut Sugiyono (2011), metode analisis deskriptif adalah statistik yang digunakan untuk menganalisis data dengan cara mendeskripsikan atau menggambarkan data yang telah terkumpul sebagaimana adanya tanpa bermaksud membuat kesimpulan yang berlaku untuk umum atau generalisasi. Termasuk dalam statistik deskriptif adalah penyajian melalui tabel, grafik, diagram lingkaran, pictogram, modus, median, mean, desil, persentil, perhitungan persebaran data melalui perhitungan rata-rata dan standar deviasi, perhitungan presentase.

Setelah dilakukan penjelasan dengan statistik deskriptif, maka selanjutnya penulis melakukan pengujian terhadap data panel agar menemukan model terbaik untuk bisa menjelaskan hipotesis yang ada. Pengujian ini terdiri dari Uji Chow, Uji Lagrange Multiplier, dan Uji Hausman. Model yang akan menjadi pilihan dalam menjelaskan hipotesis adalah model Common Effect, Fixed Effect, dan Random Effect. Alur pengujian dijelaskan dalam Gambar 3. 


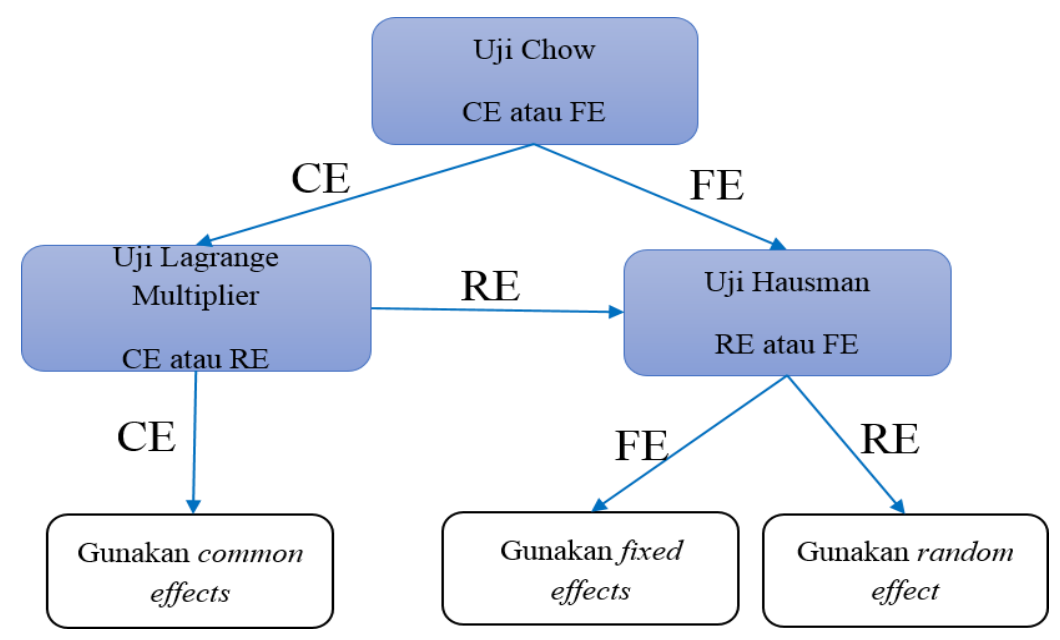

Gambar 3. Alur Pemilihan Model Penelitian

Sumber: Diolah penulis

Setelah dilakukan pemilihan model sesuai dengan data yang kita peroleh, maka selanjutnya adalah melakukan uji asumsi klasik terhadap data tersebut. Uji asumsi klasik tersebut meliputi uji autokorelasi, uji normalitas, uji multikolinearitas, dan uji heteroskedastisitas.

Uji autokorelasi dapat dilakukan dengan menggunakan metode grafik, uji DurbinWatson, uji Run, dan dengan Lagrange Multiplier (LM) (Nachrowi, 2006). Uji multikolinearitas dapat dilakukan dengan menggunakan analisis matriks korelasi antar variabel-variabel bebas, jika hasilnya cukup tinggi (biasanya 80\%) maka hal tersebut menandakan adanya multikolinearitas. Uji multikolinearitas juga bisa dengan melakukan analisis terhadap nilai toleransi dan Variance Inflation Factor (VIF) (Nachrowi, 2006). Uji heteroskedastisitas dapat dilakukan dengan melakukan uji formal (uji Breeusch-Pagan-Godfrey dan uji White) dan analisa terhadap hasil plots data dalam bentuk diagram. Uji normalitas data dapat dilakukan dengan uji Kolmogorov-Smirnov dan analisa terhadap hasil normal probability plots.

Pengujian regresi linear berganda dilakukan dengan model yang sesuai dengan data penelitian untuk menjelaskan pengaruh variabel bebas terhadap variabel terikat secara simultan (Uji Signifikansi F). Secara individu, variabel bebas berpengaruh terhadap variabel terikat penelitian dapat dijelaskan dalam uji statistik t (uji t).

\section{PEMBAHASAN}

\section{Hasil Pemilihan Sampel}

Pemilihan sampel dari penelitian ini menggunakan metode purposive sampling, yaitu pemilihan dengan kriteria-kriteria tertentu. Penggunaan metode ini diharapkan mampu untuk mendapatkan perusahaan-perusahaan yang sebanding sehingga data yang dihasilkan tidak terjadi perbedaan yang terlalu besar.

Data awal dari penelitian ini adalah jumlah perusahaan yang terdaftar di BEI pada 
Oktober 2016 yang berjumlah 539 Perusahaan. Sampel yang digunakan penulis adalah perusahaan yang terdaftar sejak 2009-2015. Hanya perusahaan yang lengkap data laporan keuangannya saja yang diambil dalam sampel ini. Selanjutnya perusahaan yang diklasifikasikan sebagai sektor keuangan dikeluarkan dari sampel yang ada. Perusahaan dengan penghasilan yang terkena pajak penghasilan yang bersifat final juga dikeluarkan dari sampel (properti, real estate, dan pelayaran). Data perpajakan dari perusahaan juga harus dijelaskan dalam laporan keuangannya, jika tidak ada maka harus dikeluarkan juga dari sampel. Serta perusahaan yang rugi dikeluarkan dari sampel. Hasil pemilihan sampel berdasarkan purposive sampling dapat dilihat pada Tabel 1 Hasil Purposive Sampling.

Penelitian ini dilakukan dalam rentang waktu selama tujuh tahun mulai tahun 20092015. Rentang waktu ini mencakup perusahaan untuk pra-observasi dan observasi. Dalam jangka waktu tersebut jika terdapat perusahaan yang tidak lengkap data laporan keuangannya, maka dikeluarkan dalam sampel penelitian. Setelah dilakukan pemilihan sesuai dengan kriteria yang ada maka diperoleh perusahaan sampel sejumlah 37 perusahaan. Data yang digunakan adalah selama dua tahun sehingga data yang terkumpul adalah 74 perusahaan dalam dua tahun observasi.

Tabel 1. Hasil Purposive Sampling

\begin{tabular}{|c|c|c|c|}
\hline No & Kriteria & Total & Satuan \\
\hline 1 & $\begin{array}{l}\text { Perusahaan terdaftar di BEI sampai dengan Oktober } \\
2016\end{array}$ & 539 & Perusahaan \\
\hline \multicolumn{4}{|c|}{ Dikurangi } \\
\hline 2 & Perusahaan yang terdaftar di BEI setelah 2009 & 155 & Perusahaan \\
\hline 3 & $\begin{array}{l}\text { Perusahaan dengan laporan keuangan tidak lengkap } \\
\text { selama tahun penelitian (tidak menerbitkan laporan } \\
\text { keuangan pada tahun penelitian) }\end{array}$ & 182 & Perusahaan \\
\hline 4 & Perusahaan sektor keuangan & 66 & Perusahaan \\
\hline 5 & $\begin{array}{l}\text { Perusahaan yang penghasilannya dikenai pajak } \\
\text { penghasilan final }\end{array}$ & 52 & Perusahaan \\
\hline 6 & $\begin{array}{l}\text { Perusahaan yang tidak memiliki kelengkapan data } \\
\text { variabel yang diteliti }\end{array}$ & 47 & Perusahaan \\
\hline & Total Sampel & 37 & Perusahaan \\
\hline & Jumlah Tahun & 2 & Tahun \\
\hline & Jumlah Data & 74 & $\begin{array}{l}\text { Perusahaan- } \\
\text { tahun }\end{array}$ \\
\hline
\end{tabular}

Sumber : Diolah Penulis dari Laporan Keuangan Perusahaan yang Terdaftar di BEI.

\section{Statistik Deskriptif}

Statistik deskriptif menggambarkan data yang terlah terkumpul sebagaimana adanya tanpa bermaksud untuk membuat kesimpulan yang berlaku untuk umum atau generalisasi (Sugiyono, 2010).

\section{Statistik Deskriptif Variabel Berskala Rasio}

Skala rasio adalah skala yang mencakup semua skala yaitu nominal, ordinal, dan interval 
Pengaruh Tax Avoidance Risk Terhadap Cash Holding ...

disamping memberikan keterangan tentang nilai absolut dari objek yang diukur (Suharyadi, 2003). Skala rasio dalam statistik ini dapat dilihat dalam Lampiran 2 Statistik Deskriptif Variabel Berskala Rasio. Dari tabel tersebut dapat dijelaskan sebagai berikut:

\section{Cash to Assets}

Variabel terikat Cash to Assets memiliki rata-rata -0,1125091. Nilai minimum Cash to Assets adalah 0,0045952 dan nilai maksimumnya 0,2889188. Range atau jarak antara nilai minimum dengan nilai maksimum adalah 0,2843236.

\section{Cash to Sales}

Variabel terikat Cash to Sales memiliki rata-rata 0,19579. Nilai minimum Cash to Assets adalah 0,00734 dan nilai maksimumnya 1,66418. Range atau jarak antara nilai minimum dengan nilai maksimum adalah 1,65684 .

\section{Cash ETR}

Variabel bebas Cash ETR memiliki rata-rata 0,43780. Nilai minimum Cash ETR adalah 0,00241 dan nilai maksimumnya 4,18375. Range atau jarak antara nilai minimum dengan nilai maksimum adalah 4,18134.

\section{Market to Book Ratio}

Variabel kontrol Market to Book Ratio memiliki rata-rata 2,12603. Nilai minimum Market to Book Ratio adalah 0,19547 dan nilai maksimumnya 12,17899. Range atau jarak antara nilai minimum dengan nilai maksimum adalah 11,98352.

\section{Size}

Variabel kontrol Size memiliki rata-rata 28,57793. Nilai minimum Size adalah 25,82187 dan nilai maksimumnya 33,13405. Range atau jarak antara nilai minimum dengan nilai maksimum adalah 7,31218.

\section{Leverage}

Variabel kontrol Leverage memiliki rata-rata 0,46430. Nilai minimum Leverage adalah 0,13567 dan nilai maksimumnya 0,93596 . Range atau jarak antara nilai minimum dengan nilai maksimum adalah 0,80029 .

\section{Capex}

Variabel kontrol Capex memiliki rata-rata 0,06368. Nilai minimum Capex adalah 0 dan nilai maksimumnya 0,27084. Range atau jarak antara nilai minimum dengan nilai maksimum adalah 0,27084.

\section{Volatility of Cash Flow}

Variabel kontrol Volatiliy of Cash Flow memiliki rata-rata 0,07038. Nilai minimum Volatiliy of Cash Flow adalah 0,003 dan nilai maksimumnya 0,7105. Range atau jarak antara nilai minimum dengan nilai maksimum adalah 0,70749.

\section{$R \boldsymbol{D}$}


Variabel kontrol $R n D$ memiliki rata-rata 0,00242. Nilai minimum $R n D$ adalah 0 dan nilai maksimumnya 0,08918. Range atau jarak antara nilai minimum dengan nilai maksimum adalah 0,08918 .

\section{Akuisisi}

Variabel kontrol Acquisition memiliki rata-rata -0,00212. Nilai minimum Acquisition adalah 0 dan nilai maksimumnya 0,07. Range atau jarak antara nilai minimum dengan nilai maksimum adalah 0,07 .

\section{After Tax Cashflow}

Variabel kontrol After Tax Cash Flow memiliki rata-rata 0,11350. Nilai minimum After Tax Cash Flow adalah 0,01331 dan nilai maksimumnya 0,42756. Range atau jarak antara nilai minimum dengan nilai maksimum adalah 0,41424 .

\section{Statistik Deskriptif Variabel Berskala Nominal}

Skala nominal merupakan skala pengukuran yang menyatakan kategori, atau kelompok dari suatu objek. Misalkan variabel dividen, pemberi dividen dan tidak memberikan dividen (Ghozali, 2013). Pada pengujian ini, fungsi yang digunakan adalah minimum, maximum, dan sum untuk mengetahui persebaran data penelitian. Hasil uji statistik deskriptif variabel nominal digambarkan pada Tabel 2 Statistik Deskriptif Variabel Berskala Nominal.

Dari data observasi didapat bahwa terdapat 51 perusahaan (69\%) membagikan dividennya terhadap para pemegang saham dari total 74 perusahaan tahun. Data dividen ini merupakan variabel dummy.

Tabel 2. Statistik Deskriptif Variabel Berskala Nominal

\begin{tabular}{clcccc}
\hline No & \multicolumn{1}{c}{ Variabel } & N & Min & Max & Sum \\
\hline 1 & Dividen & 74 & 0 & 1 & 51 \\
\hline 2 & 1 agriculture & 74 & 0 & 1 & 2 \\
\hline 3 & 3 Basic Industry and Chemicals & 74 & 0 & 1 & 10 \\
\hline 4 & 4 Miscellaneous Industry & 74 & 0 & 1 & 8 \\
\hline 5 & 5 Consumer Goods Industry & 74 & 0 & 1 & 4 \\
\hline 6 & 7 Infrastructures, Utilities and & 74 & 0 & 1 & 6 \\
& Transportation & & & & \\
\hline 7 & 9 Trade, Services and Investment & 74 & 0 & 1 & 44 \\
\hline 8 & Tahun 2014 & 37 & 0 & 1 & 37 \\
\hline 9 & Tahun 2015 & 37 & 0 & 1 & 37 \\
\hline 10 & Valid N (listwise) & 74 & & \\
\hline \multicolumn{4}{l}{ Sumber: Diolah Penulis dari hasil output aplikasi STATA.14 }
\end{tabular}

Variabel dummy sektor industri menunjukkan bahwa dari 74 perusahaan observasi, 2 perusahaan (2.7\%) termasuk dalam sektor industri pertanian, 10 perusahaan (13.51\%) termasuk dalam sektor industri dasar dan kimia, 8 perusahaan (10.81\%) termasuk dalam sektor industri lain-lain, 4 perusahaan (5.41\%) termasuk dalam sektor konsumsi, 6 perusahaan 
Pengaruh Tax Avoidance Risk Terhadap Cash Holding ...

(8.11\%) termasuk dalam sektor industri infrastruktur, utility, dan transportasi, serta yang terbanyak sejumlah 44 perusahaan (59.46\%) termasuk dalam sektor industri perdagangan, jasa dan investasi.

Jumlah (sum) yang bernilai 37 pada variabel tahun 2014, dan tahun 2015 merupakan jumlah data pada setiap tahun penelitian. Hal ini menunjukkan bahwa data yang digunakan adalah data panel yang bersifat balance.

\section{Pendekatan Model dan Uji Asumsi Klasik}

Setelah dilakukan pemilihan model, maka didapatkan pendekatan model yang sesuai adalah random effect. Pada model penelitian ini perlu dilakukan uji asumsi klasik. Uji asumsi klasik ini berupa uji normalitas, uji multikolinearitas, uji autokorelasi, serta uji heteroskedastisitas. Namun dalam penelitian ini hanya dua uji normalitas dan uji multikolinearitas yang perlu dilakukan. Hal ini disebabkan penggunaan estimasi Generalized Least Square (GLS) dalam pendekatan random effects (Nachrowi, 2006). Dua pengujian lain tidak dilakukan karena penggunaan Feasible Generalized Least Squares (FGLS) sudah memfasilitasi masalah autokorelasi dan heteroskedastisitas yang tidak efisien bila dilakukan dengan OLS (Gujarati, 2004).

\section{Pengujian Regresi Berganda}

Ketepatan fungsi regresi sampel dalam menaksir nilai aktual dapat diukur dari Goodness of Fit-nya. Secara statistik, setidaknya ini dapat diukur dari nilai koefisien determinasi, nilai statistik F dan nilai statistik t (Ghozali, 2013).

\section{Koefisien Determinasi $\left(\mathrm{R}^{2}\right)$}

Koefisien determinasi pada intinya mengukur seberapa jauh kemampuan model dalam menerangkan variasi variabel terikat (Ghozali, 2013). Nilai koefisien determinasi bernilai dari nol sampai dengan satu. Semakin tinggi nilainya semakin tinggi juga pengaruh variabel bebas dalam menjelaskan variasi dari variabel terikat. Nilai dari koefisien determinasi dapat dilihat dari Gambar 4 Nilai Koefisien Determinasi $\left(\mathrm{R}^{2}\right)$. 
probabilitas dari model penelitian masih berada dibawah 0.05. Hal ini menunjukkan bahwa keputusan yang diambil adalah menolak $\mathrm{H}_{0}$. Dengan ditolaknya $\mathrm{H}_{0}$, maka Hipotesis alternatif, yaitu variabel bebas dan kontrol pada penelitian ini dapat berpengaruh secara simultan terhadap variabel terikat.

\section{Uji Signifikansi Parameter Individual (Uji Statistik t)}

Uji statistik t dilakukan dengan cara melihat tabel koefisiensi regresi dengan hasil proses regresi dari aplikasi STATA 14. Uji ini sebenarnya untuk melihat seberapa jauh pengaruh satu variabel bebas dan kontrol terhadap variabel terikat (Ghozali, 2013). H0 dari penelitian ini menjelaskan bahwa variabel bebas bukan penjelas dari variabel terikat, sedangkan $\mathrm{H} 1$ menjelaskan bahwa variabel bebas merupakan penjelas dari variabel terikat.

Keputusan dari penelitian ini bisa dilihat dari nilai t tabel dengan nilai $t$ statistik. Keputusan dapat diambil dari hasil probabilitas ( $p$-value) dari variabel bebas. Kondisi tolak H0 adalah dimana nilai probability lebih kecil dari tingkat kepercayaan 0,05 , begitu pula sebaliknya.

Hasil dari output suatu aplikasi menggunakan prinsip two-tailed, bukan one-tailed. Hal ini akan berbeda arti jika hipotesis kita menunjukkan pengaruh serta arah dari pengaruh tersebut. Jika hanya pengaruh saja, maka hasil dari aplikasi bisa langsung digunakan. Hal ini berbeda jika ternyata hipotesis kita one-tailed, maka yang harus kita lakukan adalah membagi nilai probability two-tailed test dengan 2 untuk menjadi one-tailed test (Field, 2013). Hasil perhitungan probabilitas dari output aplikasi STATA.14 disajikan dalam Gambar 6 Hasil Uji Statistik t.

Dari hasil output aplikasi STATA.14 tersebut, hipotesis dari suatu penelitian bisa diambil keputusan untuk diterima atau ditolak. Dalam hal ini pengaruh dari masing-masing variabel bebas pada penelitian dapat dilihat dengan membandingkan nilai $\mathrm{P}>|\mathrm{z}|$ dengan nilai probabilitas 0,05 pada taraf kepercayaan 95\%. Nilai $\mathrm{P}>|\mathrm{z}|$ dibagi dengan 2 untuk melihat one tailed test pada variabel yang memiliki prediksi tanda, dan $\mathrm{P}>|\mathrm{z}|$ berdasarkan two-tailed test untuk variabel yang tidak memiliki prediksi tanda.

\begin{tabular}{r|rrrrrr} 
CashtoAssets_w & Coef. & Std. Err. & $\mathbf{z}$ & P $|\mathbf{z}|$ & [958 Conf. Interval] \\
\hline CashETR & -.008017 & .0113264 & -0.71 & 0.479 & -.0302163 & .0141823 \\
Markettobook & -.0002425 & .0064913 & -0.04 & 0.970 & -.0129651 & .0124802 \\
Size & .0069594 & .0078559 & 0.89 & 0.376 & -.008438 & .0223567 \\
Laverage & -.2379911 & .0627779 & -3.79 & 0.000 & -.3610335 & -.1149488 \\
capex & -.2685989 & .1415098 & -1.90 & 0.058 & -.545953 & .0087552 \\
voltilityofCashFlow & -.0243691 & -1412498 & -0.17 & 0.863 & -.3012137 & .2524755 \\
deviden & -.0393693 & .0201285 & -1.96 & 0.050 & -.0788205 & .0000819 \\
RnDratio & -.6842542 & .8817658 & -0.78 & 0.438 & -2.412483 & 1.043975 \\
Akuisisi & .381279 & .8620073 & 0.44 & 0.658 & -1.308224 & 2.070782 \\
aftertaxcashflow & .0296283 & .1837599 & 0.16 & 0.872 & -.3305346 & .3897911
\end{tabular}

Gambar 6. Hasil Uji Statistik t

Sumber: Diolah Penulis dari hasil output aplikasi STATA.14 
Pada Gambar 6 Hasil Uji Statistik t juga dapat kita lihat bahwa ada dua variabel yang memiliki nilai probability di bawah 0,05. probability di bawah taraf signifikan 0,05 dimiliki oleh variabel Leverage dengan nilai $\mathrm{P}>|\mathrm{z}|$ sebesar 0,000 dan variabel Dividen dengan nilai $\mathrm{P}>|\mathrm{z}|$ sebesar 0,050. Selain itu ada satu variabel juga yang memiliki signifikansi dibawah 0,1 yaitu variabel CAPEX dengan nilai $\mathrm{P}>|\mathrm{z}|$ sebesar 0,058 . Hal ini berarti variabel Leverage, Dividen dan Capex adalah penjelas dari variabel terikat penelitian atau variabel Leverage, Dividen dan Capex berhubungan signifikan terhadap cash holding pada tingkat kepercayaan 95\% dan 90\%. Sedangkan variabel lainnya, yaitu Market to Book, Size, Volatility of Cash Flow, RnD, Acquisition dan After Tax Cash Flow, yang tidak memiliki nilai probabilitas di bawah 0,05 berarti tidak berpengaruh pada variabel terikat atau bukanlah penjelas dari variabel terikat penelitian.

\section{Pengujian Hipotesis}

Dengan asumsi faktor lain tetap, hipotesis kerja $\left(\mathrm{H}_{1}\right)$ penelitian ini menyatakan bahwa terdapat hubungan positif antara risiko penghindaran pajak terhadap kebijakan perusahaan untuk melakukan cash holding. Dengan demikian, untuk menilai apakah hipotesis tersebut ditolak atau diterima, harus dinilai apakah terdapat hubungan yang signifikan antara variabel bebas risiko penghindaran pajak (Cash ETR) terhadap cash holding perusahaan (Cash to Assets).

Keputusan untuk menerima $\mathrm{H}_{1}$ diambil ketika nilai probabilitas dari uji statistik $\mathrm{t}$ dengan one-tailed test (nilai $\mathrm{P}>|\mathrm{z}|$ ) lebih kecil dari 0,05 atau ketika hasil uji statistik t berada di atas titik kritis tabel. Hasil uji signifikansi parameter individual untuk variabel bebas (Cash ETR) dapat dilihat pada gambar 7 Hasil Uji Hipotesis.

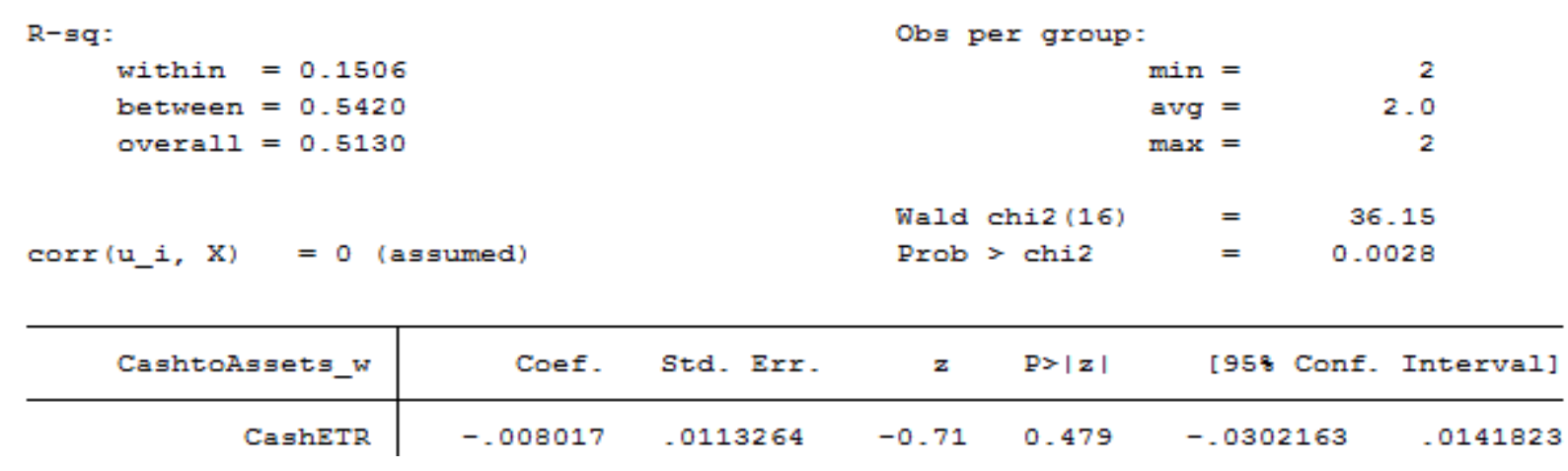

Gambar 7. Hasil Uji Hipotesis

Sumber: Diolah Penulis dari hasil output aplikasi STATA.14

Hasil dari pengolahan data menunjukan bahwa nilai $\mathrm{P}>|\mathrm{z}|$ untuk variabel bebas risiko penghindaran pajak (Cash ETR) terhadap cash holding (Cash to Assets) perusahaan adalah 0,479. Hasil dari aplikasi ini merupakan two-tailed test. Untuk melihat hubungan positif atau negatif dari variabel ini nilai probabilitas harus dibagi dengan 2 (Field, 2013). Nilai sesuai dengan onetailed test adalah 0,239 (0,479/2). Nilai probabilitas sebesar 0,239 masih berada jauh di atas nilai 0,05 . Oleh karenanya, hasil pengujian ini mengarahkan pada keputusan untuk gagal tolak 
Pengaruh Tax Avoidance Risk Terhadap Cash Holding ...

H0. Hal ini berarti pengaruh bebas Cash ETR tidak signifikan terhadap kebijakan cash holding perusahaan.

Sesuai dengan nilai koefisien dari variabel tax risk (-0.008017) dan berdasarkan onetailed test dengan sig 0.239 menunjukkan bahwa tidak ada hubungan positif signifikan antara risiko penghindaran pajak dengan cash holding perusahaan, diasumsikan bahwa faktor lain tetap. Hasil dari pengujian hipotesis pada penelitian ini ternyata berlawanan dengan penelitian yang dilakukan oleh Hanlon \& Maydew, (2013).

\section{Interpretasi dan Diskusi}

Hasil regresi sesuai dengan model random effect yang terdapat dalam Gambar 5, Gambar 6, dan Gambar 7, menunjukkan bahwa variabel bebas memiliki hubungan positif namun tidak signifikan terhadap variabel terikat dengan tingkat kepercayaan 95\%. Di dalam model penelitian ditunjukkan hasilnya negatif, yang artinya risiko penghindaran pajak pada suatu perusahaan semakin terjadi jika nilai Cash ETR semakin kecil. Hal ini menunjukkan bahwa risiko penghindaran pajak yang dihitung dengan menggunakan long run Cash ETR memiliki hubungan positif dan tidak signifikan sesuai dengan hipotesis kerja pada penelitian ini.

Hasil dari penelitian ini ternyata tidak sejalan dengan penelitian yang dilakukan oleh Hanlon \& Maydew (2013). Dalam jurnalnya yang berjudul "Understanding Why Firms Hold So Much Cash: A Tax Risk Explanation" dengan subjek perusahaan di Amerika, Hanlon menemukan bahwa terjadi hubungan antara risiko penghindaran pajak dengan cash holding. Hal ini disebabkan karena di perusahaan di Amerika menumpuk kas mereka untuk beberapa alasan, salah satunya untuk berjaga-jaga atas tindakan perusahaan ketika mereka melakukan tindakan penghindaran pajak. Hal ini juga berkaitan dengan aturan terhadap Uncertainty Tax Benefit yang berlaku di Amerika Serikat setelah berlakunya FIN 48 tentang pengungkapan Contingent Tax Benefit (Hanlon, Maydew, dan Saavedra, 2014). Berbeda dengan Amerika, di Indonesia peraturan tersebut tidak ada dan kondisi perusahaan di Indonesia tidak sesuai dengan aturan pengungkapan pajak yang masih jadi tanggungan di masa yang akan datang.

Selain itu perusahaan di Amerika juga dikenai pajak repatriasi ketika mengambil dana dari anak perusahaan di luar Amerika, sehingga perusahaan akan menimbun uang meraka di luar negeri sampai benar-benar dibutuhkan di perusahaan induk yang berada dalam negeri (Foley, et al, 2007). Hal ini menyebabkan cash holding perusahaan akan meningkat. Kondisi ini berbeda dengan di Indonesia, ketika perusahaan menarik dana dari luar negeri tdak dikenakan pajak lagi seperti di Amerika Serikat. Hal lain yang perlu diperhatikan adalah di Indonesia masih banyak terdapat perusahaan anak daripada perusahaan induk seperti di Amerika.

Berbeda dengan di Indonesia, ketika terjadi risiko pajak pada suatu perusahaan, maka perusahaan akan sangat berhati-hati dalam memutuskan langkah penyelesaian pajaknya. 
Perusahaan yang melakukan keberatan atas Surat Ketetapan Pajak (SKP) tetap harus membayar kewajiban perpajakannya minimal sejumlah yang disetujuinya. Hal ini tentunya akan sangat berpengaruh dengan kas yang dimiliki oleh perusahaan. Dalam hal mengajukan keberatan atas SKP, perusahaan akan dikenai denda sebesar 50\% dari kekurangan kewajiban perpajakannya jika hasil keberatan tersebut ditolak atau dikabulkan sebagian. Ketika perusahaan mengajukan banding di tingkat Pengadilan Pajak, denda yang harus dibayar menjadi 100\% dari jumlah pajak berdasarkan putusan banding ketika permohonan banding ditolak atau dikabulkan sebagian. Perusahaan akan berpikir ulang ketika akan melakukan keberatan atau banding atas kewajiban perpajakannya. Hal ini membuat risiko penghindaran pajak yang ada di perusahaan tidak mempengaruhi kebijakan cash holding.

Data dari Pengadilan Pajak menyebutkan bahwa sengketa pajak banyak dimenangkan oleh Wajib Pajak. Dari total 38.862 kasus sengketa pajak pada tahun 2011-2015, hanya 10.185 (26\%) yang dimenangkan oleh DJP. Hal ini menjadi semacam jawaban bahwa ketika masuk ke dalam ranah penghindaran pajak, kemudian perusahaan melakukan keberatan dan banding, mereka siap untuk memenangkan sengketa tersebut. Hal ini bertolak belakang dengan yang terjadi di Amerika Serikat, dimana salah satu tujuan dari cash holding ini merupakan antisipasi jika terjadi kekalahan di persidangan pajak.

Dari penelitian ini juga diketahui, ternyata hal lain yang mempengaruhi secara signifikan cash holding perusahaan adalah leverage, dividend, dan capex. Hal ini sejalan dengan penelitian yang dilakukan oleh Jinkar (2013). Variabel leverage dan dividend mempengaruhi secara signifikan kebijakan cash holding namun untuk penelitiannya mengatakan bahwa untuk variabel capex tidak berpengaruh signifikan. Penelitian yang dilakukan oleh Subekti (2012) juga mengatakan hal yang sama, bahwa kebijakan cash holding perusahaan diantaranya dipengaruhi oleh leverage dan dividend.

\section{SIMPULAN DAN SARAN}

\section{Simpulan}

Berdasarkan hasil penelitian dan pembahasan yang telah dijelaskan pada bab IV, maka dapat diambil kesimpulan bahwa hipotesis "Risiko penghindaran pajak berpengaruh positif terhadap kebijakan perusahaan menahan kas" ditolak karena risiko pajak penghasilan (Cash ETR ) memiliki nilai probability sesuai dengan one-tailed test sebesar 0,239 yang lebih besar dari 0,05. Artinya risiko penghindaran pajak yang dihitung dengan (Cash ETR) tidak memiliki pengaruh positif signifikan terhadap kebijakan cash holding suatu perusahaan. Namun, dalam penelitian ini ditemukan beberapa variabel kontrol yang berpengaruh signifikaan terhadap variabel terikat yaitu Leverage dan Dividen (dalam tingkat kepecercayaan 95\%) serta Capital Expenditure (Capex) (dalam tingkat kepecercayaan 90\%). Ketiga variabel berpengaruh negatif, 
Pengaruh Tax Avoidance Risk Terhadap Cash Holding ...

jadi semakin tinggi nilai ketiga variabel tersebut, maka semakin rendah nilai dari cash holding dari suatu perusahaan.

\section{Keterbatasan Penelitian}

Pada penelitian ini objek penelitian terbatas pada perusahaan terdaftar di Bursa Efek Indonesia karena sulit mendapatkan Catatan atas Laporan Keuangan perusahaan yang tidak terdaftar di Bursa Efek Indonesia, jangka waktu penelitian yang pendek kemungkinan akan memberikan hasil yang kurang maksimal, dan belum memasukkan variabel kontrol kurs dan inlasi yang mungkin berpengaruh dalam penentuan kebijakan cash holding dari suatu perusahaan.

\section{Saran}

Berdasarkan hasil pembahasan dan simpulan penelitian ini, penulis mengajukan beberapa saran, antara lain: (1) penelitian selanjutnya untuk menggunakan data seluruh perusahaan yang ada di Indonesia, bukan hanya yang terdaftar di Bursa Efek Indonesia saja, agar hasil yang didapatkan lebih representatif untuk menjelaskan model yang ada; (2) Penelitian selanjutnya dapat mempertimbangkan untuk menggunakan metode pengukuran lain terhadap variabel bebas risiko peghindaran pajak. Proxy lain seperti ETR (Cash ETR, GAAP ETR), BTD (Book Tax Different), BTG (Book Tax Gap Residual), dll dapat digunakan untuk menilai risiko penghindaran pajak. (3) Pembaca laporan keuangan, khususnya shareholder dapat menggunakan informasi dalam penelitian ini sebagai sarana untuk menilai kebijakan cash holding yang dilakukan oleh perusahaan.

\section{DAFTAR PUSTAKA}

Bates, T. W., Kahle, K., \& Stulz, R. M. 2009. Why do U.S. Firms Hold So Much Than They Used To? Journal of Finance, 64(5), 1985-2021.

Baumol, W. J. 1952. The Transactions Demand for Cash: An Inventory Theoretic Approach. Oxford Journals.

Bragg, S. 2012. What Is The Purpose Of Financial Statements? Diakses pada 23 September 2016 dari http://www.accountingtools.com/questions-and-answers/what-is-the-purpose-of-financialstatements.html.

Chege, G. 2014. Types, Nature of Conflicts, Agent Costs and Resolution In Agent Relationship In An Organization.

Chen, S., et al. 2010. Are Family Firms More Tax Aggressive Than Non-Family firms? Journal of Financial Economics, 95(1), 41-61.

Desai, M. 2005. Corporate Profits, 19(4), 171-192. http://doi.org/10.2307/2225251.

Detik.com. 2016. Menkeu: 2.000 Perusahaan Asing di RI Tak Bayar Pajak Selama 10 Tahun. Retrieved September 23, 2016, from http://finance.detik.com/berita-ekonomi-bisnis/d-3169957/menkeu2000-perusahaan-asing-di-ri-tak-bayar-pajak-selama-10-tahun.

Dhaliwal, D. S., et al. 2011. Corporate Tax Avoidance and the Level and Valuation of Firm Cash Holdings. SSRN Electronic Journal, 41.

Dittmar, A. 2005. Corporate Governance and the Value of Cash Holdings Corporate Governance and The Value of Cash Holdings, 1-37. 
Dittmar, A., Mahrt-Smith, J., \& Servaes, H. 2003. International Corporate Governance and Corporate Cash Holdings. The Journal of Financial and Quantitative Analysis, 38(1), 111-133.

Dyreng, S. D., Hanlon, M., \& Maydew, E. L. 2008. Long-Run Corporate Tax Avoidance. The Accounting Review, 83(1), 61-82.

Dyreng, S. D., Hanlon, M., \& Maydew, E. L. 2010. The Effects of Executives on Corporate Tax Avoidance. Accounting Review, 85(4), 1163-1189.

Faulkender, M., \& Wang, R. 2006. Corporate Financial Policy and The Value Of Cash. Journal of Finance, 61(4), 1957-1990.

Field, A. 2013. Discovering Statistics Using SPSS. International Statistical Review (3rd ed., Vol. 81). SAGE Publication Ltd. http://doi.org/10.1111/insr.12011_21

Foley, C. F., et al. 2007. Why Do Firms Hold So Much Cash ? The University of Texas at Austin The University of Texas at Austin and NBER Why Do Firms Hold So Much Cash? A Tax-Based Explanation. Technology, (512).

Ghozali, I. 2013. Aplikasi Analisis Multivariete dengan Program IBM SPSS 23 (8th ed.). Semarang: Badan Penerbit Universitas Diponegoro.

Gujarati, D. N. (2004). Basic Econometrics. New York. http://doi.org/10.1126 /science.1186874.

Hanlon, M., Hoopes, J. L., \& Shroff, N. 2014. The Effect of Tax Authority Monitoring and Enforcement on Financial Reporting Quality. Journal of the American Taxation Association, 36(2), 137-170.

Hanlon, M., \& Maydew, E. 2013. Understanding Why Firms Hold So Much Cash: A Tax Risk Explanation. De Trabajo, Mit, Diakses pada 20 September 2016 dari https://scprod2lb.mccombs.utexas.edu/ /media/Files/MSB/Departments/Accounting/Brownbag papers/HMS Cash paper 217 2013.pdf.

Hanlon, M., Maydew, E. L., \& Saavedra, D. 2014. The Taxman Cometh: Does Tax Uncertainty Affect Corporate Cash Holdings? MIT Working Paper.

Hanlon, M., \& Slemrod, J. 2009. What does Tax Aggressiveness Signal? Evidence from Stock Price Reactions to News About Tax Shelter Involvement. Journal of Public Economics, 93(1-2), 126-141.

Hukumonline.com. (2009). ICW: Sampoerna Pengutang Pajak “Terbesar.” Diakses pada 28 September 2016 dari http://www.hukumonline.com/berita/baca/hol22748/icw-sampoerna-pengutang-pajakterbesar.

Jensen, C., \& Meckling, H. 1976. Theory of the Firm : Managerial Behavior , Agency Costs and Ownership Structure. Journal of Financial Economics, 3, 305-360.

Jensen, M. C., \& Jensen, B. M. C. 1986. Agency Costs Of Free Cash Flow, Corporate Finance, And Takeovers. The American Economic Review, 76(2), 323-329.

Jinkar, R. T. 2013. Analisa Faktor- Faktor Penentu Kebijakan Cash Holding Perusahaan Manufaktur di Indonesia. Jurnal Departemen Akuntansi Universitas Indonesia.

Kim, J. B., Li, Y., \& Zhang, L. 2011. Corporate Tax Avoidance and Stock Price Crash Risk: Firm-Level Analysis. Journal of Financial Economics, 100(3), 639-662.

Miller, M. H., \& Orr, D. 1966. A Model of the Demand for Money by Firms. The Quarterly Journal of Economics, 80(3), 413-435.

Mulligan, C. B. 1997. Scale Economies, the Value of Time, and the Demand for Money: Longitudinal Evidence from Firms. Journal of Political Economy, 105(5), 1061-1079.

Nachrowi, D. N. 2006. Pendekatan Populer dan Praktis EKONOMETRIKA. (A. D. Prayoga, Ed.) (14th ed.). Lembaga Penerbit FE UI.

Opler, T., et al. 1999. The Determinants And Implications Of Corporate Cash Holdings In China. Journal of Financial Economics, 52(1999), 3-46.

Pfanner, E. 2012. European Countries Seek More Taxes From u.s. Multinational. Wall Street Journal, November 1.

Republik Indonesia. Undang-Undang Negara Republik Indonesia Nomor 6 Tahun 1983 tentang Ketentuan 
Pengaruh Tax Avoidance Risk Terhadap Cash Holding ...

Umum dan Tata Cara Perpajakan sebagaimana telah diubah terakhir dengan Undang-undang Nomor 16 Tahun 2009. Menteri Keuangan Republik Indonesia. Jakarta.

Schmidt, M. 2016. Balance Sheet B/S (Statement of Financial Position) Explained. Diakses pada September 23, 2016, from https://www.business-case-analysis.com/balance-sheet.html.

Sekaran, U. 2006. Metodologi Penelitian untuk Bisnis. Jakarta: Salemba Empat.

Sikka, P., \& Hampton, M. P. 2005. The Role of Accountancy Firms In Tax Avoidance: Some Evidence and Issues. Accounting Forum, 29 (3 SPEC. ISS.), 325-343.

Soewadji, J. 2012. Pengantar Metodologi Penelitian. Jakarta: Penerbit Mitra Wacana Media.

Subekti. 2012. Cash Holding Perusahaan Non Keuangan di Bursa Efek Indonesia Tahun 2003- 2010.

Sugiyono. 2010. Metode Penelitian Bisnis. Pendekatan Kuantitatif, Kualitatif dan R \& D. Bandung: Alfabeta, 15(2010), 90.

Suharyadi. 2003. Statistika untuk Ekonomi \& Keuangan Modern (1 ${ }^{\text {st }}$ ed.). Jakarta: Salemba Empat. 